\title{
The Development and Scope of Custody Evaluation in Child and Adolescent Psychiatry in Korea
}

\author{
Young Sook Kwak \\ Emeritus Professor, Department of Psychiatry, Jeju National University College of Medicine, Jeju, Korea
}

Divorce is no longer a rare occurrence in Korea. With the divorce rate constantly on the rise, a total of 110,879 couples divorced in 2019, marking a 2.0\% year-over-year increase, according to the data released by Statistics Korea in December 2019 [1].

The problems of a divorced family are not limited to the problems between the divorced couple, but also their children who may be equally affected by them. During a divorce, it is therefore of utmost importance to decide which options and processes are in the best interests of the children.

The purpose of the child custody evaluation is to adjust the custody environment in a manner that safeguards the best interests of the child. Provisions for the best possible environment can be made for a child or adolescent by providing a fair and objective custody evaluation that can minimize the trauma and sequelae of the divorce process; thus, contributing to promoting healthy development and preventing mental health problems. According to a (non-Korean) report, half of divorced families go through custody conflicts, half of which are beyond considerable conflicts [2]. Major custody disputes that may arise in relation to child protection in divorce cases concern custodianship, visitation, child care expenses, and child abduction.

In 2017, an expert advisory system was introduced in Korea to provide assistance to family court and mediation proceedings with regards to divorcing families and custody issues [3]. With this, a referral procedure was established so that expert opinions could be sought from psychiatrists and psychologists, and pedologists were appointed as advisory committee members whenever a professional evaluation was additionally required in a custody-related decision-making process. Furthermore, family courts have long been operating family court investigation services in which dedicated investigators take charge of stable welfare services for them [4]. Cooperation with family court investigators responsible for familial cases is indispensable in cases involving custody eval-

This is an Open Access article distributed under the terms of the Creative Commons Attribution Non-Commercial License (https://creativecommons.org/licenses/by-nc/4.0) which permits unrestricted non-commercial use, distribution, and reproduction in any medium, provided the original work is properly cited. uation because they serve as liaison with external experts.

In general, cases that have not reached consensus via divorce mediation are referred to mental health professionals for child custody evaluation. The primary role of a custody evaluator is to assist the judge by providing analysis results that help understand the complex familial dynamics in the context of the child's best interests. Apart from this, the family involved is also provided with useful information that can assist them in solving their own problems through the intervention of a custody evaluator [5].

In Korea, however, child psychiatrists rarely participated in the child custody evaluation process. Despite the memorandum of understanding (MOU) established between Seoul Family Court and the Korean Academy of Child and Adolescent Psychiatry in 2015, no concrete institution or system was put in place as a liaison between the court and the clinic. There have been rare exchanges and consultations at the private level as it has been difficult to activate professional consultation services for lack of institutionalization of the formal referral procedure.

In 2016, practical cooperation between child psychiatrists, judges, investigators, and lawyers began with the launch of regular official joint seminar with the participation of the Joint Research Committee for Parental Education, Research Group on Family and Child Protection Practices, and Korean Medical Association of Child and Adolescent Psychotherapy (KMACAP) under the aegis of the Seoul Family Court. This led to the establishment of the Korean Society for Child Rights Advocacy in September 2017. The theme of the inauguration symposium was "Divorce and Child Protection." Through this process, child psychiatrists were registered as court consultants pursuant to the expert advisory system and referrals to the registered consultants for custody evaluation have been actively in place since then. The court-registered child psychiatrists commissioned to provide custody evaluation established the Research Group on Custody Evaluation of KMACAP. At the beginning, most of them were unfamiliar with the process of custody evaluation, and above all, with the court systems and procedures. The related terminology 
was also unfamiliar. Understanding these procedures, terminology, and systems is essential for communication with other professional areas. For example, it is important to know that forensic evaluation is not subject to the obligation of confidentiality with regard to the interviewees' statements. Training forensic evaluators is necessary to familiarize them with the procedure of providing information, obtaining a signed consent form, and writing custody evaluation reports.

Custody evaluation services are still being provided by a limited number of committed pioneering colleagues. For the past two years, they have held monthly custody evaluation study meetings and autodidactically sought their own professional development as evaluators by reading foreign papers in the group and sharing their own custody evaluation experiences in case discussion sessions. At the same time, they have held regular meetings with the court to discuss practical problems encountered during evaluation.

This research group plans to compile guidelines and manuals customized to the Korean situation based on reviewing the guidelines released by the American Psychological Association, Association of Family and Conciliation Courts, and American Academy of Child and Adolescent Psychiatry, and present evaluation case studies to share them with the fellow members. Firstly, the authors from the group wrote three review articles in which they systematically arranged and summarized the most basic and important contents that every child and adolescent psychiatrist needs to know. The main topics of these three review articles are the concept and periodic background of custody evaluation, custody evaluation process and writing report, and custody evaluation in special situations: domestic violence and parental alienation syndrome.
Upon completion of the final version of the envisaged guidelines and manual applicable to practical settings, the intension is to provide training workshops for all members of the Korean Academy of Child and Adolescent Psychiatry. Child psychiatrists should be prepared to provide custody evaluation by referral from the court. Ideally, this can be done by including child custody evaluation in the clinical curriculum for Child Psychiatry fellows and giving them opportunities for actually conducting custody evaluation.

In this editorial, the author briefly introduces and summarizes the background of the development of the Korean Society for Child Rights Advocacy and the Research Group on Custody Evaluation of KMACAP, along with their work over the past several years. We welcome any communication about co-research work or academic meetings from you.

\section{REFERENCES}

1) Statistics Korea. Vital statistics in December 2019 [cited 2020 March 5]. Available from URL: http://kostat.go.kr/portal/eng/ pressReleases $/ 8 / 1 /$ index.board? bmode $=$ read $\& b S e q=\& a S e q=38102$ $2 \&$ page $\mathrm{No}=1 \&$ row $\mathrm{Num}=10$ \&navCount $=10 \&$ currPg $=\&$ searchInfo $=\& s$ Target $=$ title \&sTxt $=$.

2) Maccoby EE, Mnookin RH. Dividing the child: social and legal dilemmas of custody. Cambridge, MA: Harvard University Press; 1992.

3) Seoul Family Court. Guidance to consultation on familial judgment, familial mediation;2017 [cited 2020 Feb 2]. Available from URL: http://yeslaw.com/lims/front/page/fulltext.html?pAct=view \&pPromulgationNo $=180178 \#$ nolink.

4) Song HJ. The human resources and duties of the family court probation officer in domestic relations cases. Korean J Fam Law 2012; 26:43-66.

5) Stahl PM. Conducting child custody evaluations: from basic to complex issue. Thousand Oaks, CA: SAGE Publication;2011. 